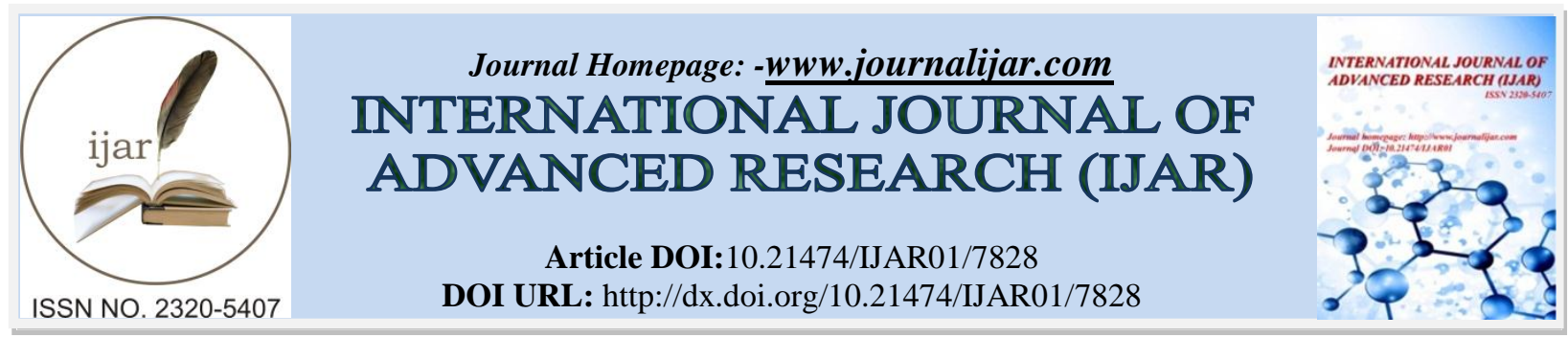

RESEARCH ARTICLE

\title{
IMPLEMENTATION STUDY OF ACCRUAL-BASED ACCOUNTING IN REGIONAL GOVERNMENT ENTITIES.
}

Andi Kusumawati, Arifuddin and Rahmawati HS.

Lecturer at the Faculty of Economics and Business.Hasanuddin University, Makassar, Indonesia.

\section{Manuscript Info}

\section{Manuscript History}

Received: 7 August 2018

Final Accepted: 9 September 2018

Published: October 2018

Keywords:-

accrual-based accounting, regional government entities, government policy.

\begin{abstract}
This research was conducted with the aim of analyzing and reviewing the implementation of accrual-based accounting in local government entities. In the first year, the study was conducted in the form of instruments monitoring the implementation of accrual-based accounting compiled based on Government Accounting Standards according to Government Regulation (PP) No. 71 of 2010. The object of research was the Financial Administration Officer (PPK) and the Regional Finance Management Officer (PPKD) of the Makassar City Government which is located in 51 Regional Work Units (SKPD). Research uses quantitative methods with descriptive analysis with index methodology. The results were obtained, that of the 16 variables studied, there were 5 variables, namely cash and cash equivalents, receivable, non-permanent investments, fixed assets, and Construction in progress, not yet believed to be in accordance with the application of Government Accounting Standards. And the results of the study and analysis regarding the implementation of accrual-based accounting in government entities for the first year were obtained in the form of instruments to monitor the implementation of a government policy in the accountability of regional financial management. In addition, the results of this study are the development of accounting theory, especially government accounting theory that has existed so far, so that the results of the study are used as material in the preparation of course teaching materials. For the second year, the results of this study are expected to be continued by making a more complex study model, by examining the factors that influence the application of accrual accounting policies. For the third year, in addition to developing a study model as well as developing research objects. For regional entities, the results of the study can be used as material in developing resources within the local government organizational structure.
\end{abstract}

Copy Right, IJAR, 2018,. All rights reserved.

\section{Introduction:-}

The State Finance Law Number 17 of 2003 stipulates that the accountability report for the implementation of APBN / APBD was prepared and presented in accordance with Government Accounting Standards (SAP). By regulating 
the law, the Government Accounting Standards have legal force in an effort to improve the quality of government financial reports in Indonesia (Bastian, 2010).

Government Accounting Standards (SAP) were first established by Government Regulation (PP) No. 24 of 2005. SAP which was established in 2005 uses the basis of Cash Toward Accrual (CTA) accounting, which is to use the accrual - based accounting on asset, liability and equity accounts and Cash - based accounting for income, expenditure and financing accounts.

Trends the adoption of accrual-based accounting in the government sector continues to develop in various countries in the world, preceded by OECD member countries (Organization for Economic Co-operation and Development) such as the United Kingdom, Canada, the United States, Australia and New Zealand. Many things were behind the development of the accrual basis. OECD countries consider that the use of the accrual-based will be able to increase the quantity and quality of financial statement information which is then useful in decision making and public accountability. With the quality of information obtained, the government will be able to make efficient and effective decisions in the management of state finances. In addition to this, accountable and transparent financial information will definitely support the supervision process appropriately.

Moving to an accrual-based is a large project that involves many challenges and issues both technical and cultural issues. In the PSC Study 14 "Transition to the Accrual Basis of Accounting: Guidance for Governments and Government Entitie" which was published in December 2003, provides guidance to assist governments and government institutions that want to migrate to the accrual - based accounting. In more depth, Study 14 Public Sector Committee (2003) states that accrual-based reporting is useful in evaluating government performance related to service costs, efficiency, and achievement of objectives. With accrual-based reporting, users can identify the government's financial position and changes, how the government funds its activities in accordance with its funding capabilities so that the actual capacity of the government can be measured. Accrual-based government accounting also allows the government to identify opportunities to use future resources and realize good management of these resources.

In the transitional period in Indonesia, Government Accounting Standards (SAP) Accruals were developed from SAP as stipulated in PP 24/2005 which has been referred to the International Public Accounting Standards (IPSAS) and takes into account the laws and conditions of Indonesia. SAP which is stipulated by PP 24/2005 based on "Cash Toward Accrual (CTA)" has mostly referred to accrual-based accounting practices. On October 22, 2010, issued PP 71/2010 concerning Government Accounting Standards (SAP) Accrual changed the direction of the Indonesian government accounting base from cash to accruals to full accruals. In accordance with the agreement between the government and the House of Representatives, the implementation of this accrual-based will be implemented in stages until its full implementation in 2015. In PP 71/2010 the arrangements include accrual-based SAP and cashbased SAP to accruals. Accrual-based SAP is contained in Annex I and was valid from the date of stipulation and can be immediately applied by each entity. Cash-Based SAP Towards Accruals in Appendix II applies during the transition period for entities that were not ready to implement Accrual-Based SAP. This means that the Government has set since the issuance of PP 71/2010 up to 2015 was a period of transition to full accruals which certainly requires a mature and appropriate strategy to be able to realize accrual-based accounting in the government sector.

Changes in the accounting basis used by an entity bring no small consequences. Resource readiness, both human resources and other resources need to be prepared. The results of research from Brussels (1997) show that the change from cash-based accounting to accrual-based accounting requires significant training costs. In the framework of implementing the accrual-based SAP, the State (2015) conducts research related to factors that influence the readiness of local governments in implementing SAP. The results of his research found that it needed the development and improvement of human resources, organizational commitment, and information technology support. Usman's research, et al (2014) on the analysis of factors influencing the implementation of accrual accounting in local government entities found that the level of government accounting for the work unit level only reached the level of 30.06\%, or very low. The Greek study conducted by Stamatiadis, et. al (2009) also found that accrual adoption was quite low after six years of implementation.

Regional financial accountability through the accounting process by using accounting policies set out in the Government Accounting Standards was the responsibility of financial managers to the public. Regional financial accountability carried out by the government to the public as executor of financial management in agency theory 
shows the relationship between the principal and agent. Jensen and Meckling (1976) see the agency relationship as a contract in which the principal, in this case the community, hires another person (agent) in this case the government to do some services for their benefit by delegating some authority to the decision making agent. Agency problems arise if principals and agents were utility maximizers (Jensen and Meckling, 1976). The principal wants to get the maximum return, while the agent wants to get the maximum compensation.

According to public policy implementation theory from George C. Edward (1980) that many factors influence the success of a policy implementation. These factors include: communication, resources, disposition, and bureaucratic structure. From the communication side, a policy must be seen as the goals and objectives of the policy that must be transmitted to the target group so as to reduce implementation distortions that can lead to resistance from the target group.

The successful implementation of a policy or regulation must also be supported by resources. Resources can be human resources or financial resources. In addition, the success of implementation was also supported by the disposition or character and characteristics of commitment, honesty, and democratic nature. Public policy implementation theory from George C. Edward (1980) was used by Ismail (2016) in examining the factors that influence accrual-based SAP implementation, and found that communication, resources, disposition, and bureaucratic structure. Influence policy implementation.

Based on the theory of public policy implementation of George C. Edward (1980) mentioned above, then in this study will be tested and analyzed the implementation of accrual-based accounting policies that have been running for more than two budget years on regional entities. Testing will be carried out using the index methodology as previously done by researchers (Christiaens, 1999, Cohen and Kaimenaki, 2007).

Testing of the implementation of accrual-based accounting policies that have been running for approximately two years was carried out in the form of instruments derived from the accrual-based accounting policy. Therefore, the instrument starts from general policies to elements of financial statements.

The purpose of this study was to analyze and examine the implementation of accrual - based accounting in local government entities in accordance with the applicable Government Accounting Standards using the index methodology. And benefits of research that the implementation of accrual - based accounting in government entities needs to be assessed in order to obtain information regarding the implementation of accrual - based accounting in government entities. The level of implementation of accrual-based accounting will be measured using an index based on an accounting basis and the characteristics set forth in Government Accounting Standards. The results of this analysis and study were expected to provide index instruments used in assessing the implementation of accrual based accounting in government entities.

\section{Literature Review and Concepts}

\section{Theory of Public Policy Implementation}

According to the theory of public policy implementation George C. Edward (1980) that complex activities have success rates influenced by many factors, including:

1. Communication. Communication is one of the important variables that influence the implementation of public policy. Effective implementation of public policy will be implemented if decision makers know what they will do. Robbins et al. (2009: 271) added that communication within organizations was often described as formal communication. Communication variables were measured using indicators (1) transmission (2) clarity, and (3) consistency.

2. Resources. George's public policy implementation. C Edward, categorizes organizational resources consisting of staff, information, authority, facilities in the form of building, equipment, land and supplies. Sitohang and Kariono (2015) explain that resources were every source used in supporting the success of policy implementation. This resource includes human resources, budget, facilities, information and authority.

3. Disposition. Disposition is a factor that is related to the character or attitude, as well as the commitment that must be possessed by policy implementers. Robbins et al. (2009: 74) argues that organizational commitment (organizational commitment), defined as a state in which an employee siding with a particular organization and its goals and desires to maintain membership in the organization. 
4. Bureaucratic Structure. Bureaucracy is one of the institutions that most often even carry out activities as a whole. The bureaucratic organizational structure includes the mechanism and structure of the bureaucracy itself. Mechanisms in policy implementation were usually made in a Standard Operation Procedure (SOP).

\section{Agency Theory}

Jensen and Meckling (1976) found that agency relations as a contract in which the principal hires an agent to perform several services related to their interests by delegating some authority to the decision making agent. Agency problems arise if the principal and agent were utility maximizers (Jensen and Meckling, 1976). The principal wants to get the maximum return, while the agent wants to get the maximum compensation.

The main characteristic of agency relations in agency theory lies in the contract of delegation of authority and responsibility from the principal to the agent. Jensen and Meckling (1976) in agent theory see that agency relations can occur in all entities that rely on contracts, either explicit or implicit, as a reference for participant behavior. Therefore, it can be said that agency relationships occur in each entity. Agency problems among executives who were often arises were likely to maximize utility (self-interest) in the making or budgeting, because it has information advantages (information asymmetry). This happens because the executive will secure its position in the government in the eyes of the legislature and the community / people. The use of the budget by the executive / government (agents) must be accountable to the people (principals) in a transparent and accountable manner about the programs and activities that have been carried out. To monitor and evaluate the use of the budget or executive performance, the people (principals) appoint the BPK as an agent.

\section{Stewardship Theory}

Stewardship theory looks at situations where managers do not have personal interests but were more concerned with the wishes of principals. This theory was based on human behavior (behavior), human patterns (model of a man), psychological mechanisms (motivation, identification and power) in an organization practicing leadership as an aspect that plays an important role for achieving goals. This theory was rooted in psiology and sociology which leads to an attitude of service (Donaldson, 1990). This theory was how to create organizational structures that can help managers to make decisions and choices to optimize organizational performance.

The theory of stewardship assumes philosophically that human nature was essentially trustworthy, thus management can be trusted to act as well as possible for the benefit of the public and stakeholders. Donaldson (1990) suggested the core of Stewardship theory that auditors were agents of principals who act in accordance with the interests of the people (principals). In this theory, it was analogous that the leaders (executives) were not motivated for individual goals but rather were aimed at the interests of the organization and act according to the wishes of the principal (the people). Referring to this theory, steward behavior was collective, because stewards were guided by behavior and organizational goals can be achieved, stewardship theory assumes that there was a very strong relationship between organizational success and principal satisfaction.

\section{Government Accounting Standards}

Government accounting standards provide a framework for the functioning of financial management stages, namely planning and budgeting, budget execution, procurement of goods and services, administration, reporting and accountability and supervision. The Indonesian government has set a government accounting standard called Government Accounting Standards (SAP) (Bastian, 2010: 138).

The Government Accounting Standards Committee (KSAP) in drafting Government Accounting Standards refers to international practices, including International Public Sector Accounting Standards (IPSAS). The current Government Accounting Standards were Government Accounting Standards regulated in Government Regulation No. 71 of 2010 as a substitute for Government Regulation No. 24 of 2005. Government Accounting Standards regulate the accounting principles applied in preparing and presenting government financial reports. Implementation of Accounting Standards Government was carried out within the government, namely the central government, regional government, and organizational units in the central / regional government, and if according to legislation organizational units were intended to submit financial statements.

The financial statements were generated from financial transactions made in a structured report on the financial position and transactions carried out by a reporting entity. The Statement of Government Accounting Standards (PSAP) in the conceptual framework Paragraph 42 states that government financial statements use the accrual - 
based accounting for Operational Reports (LO), Reports on Changes in Equity, and Balance Sheet. As for the Budget Realization Report (LRA) and Budget Balance Change Report prepared and implemented on a cash basis. If the budget preparation was carried out on an accrual-based, the Budget Realization Report (LRA) and the Budget Amendment Change Report are also prepared on the accrual-based .

Entities that exist in government are divided into accounting entities and reporting entities. The Accounting Entity was a unit in the government that manages the budget, wealth, and obligations that carry out accounting and presents financial statements on the basis of accounting held. Reporting Entity was a government unit which consists of one or more accounting entities which according to the provisions of the legislation must present accountability reports, in the form of general purpose financial statements.

According to PP 71 of 2010, accounting principles and financial reporting are intended as provisions that are understood and adhered to by standard makers in developing standards, administering financial accounting and reporting in carrying out their activities, as well as users of financial statements in understanding the financial statements presented.

\section{Empirical Review}

Juniaty Ismail's (2016) study of factors influencing the accrual-based SAP implementation in the Gorontalo Provincial Government found that communication, organizational resources consisted of staff, information, authority, facilities in the form of building, equipment, land and supplies, which supported the successful implementation of a Policy. Disposition was a factor that is related to the character or attitude, as well as the commitment that must be possessed by policy implementers. Implementers not only have to know what to do and have the capacity to do it, but also must have the will (attitude) in implementing a policy and the bureaucracy was one of the institutions that most often even carry out activities.

The research Usman et al (2014) on the analysis of factors influencing the implementation of accrual accounting in local government entities found that the level of application of accounting to the government for the work unit level only reached the level of $30.06 \%$, or very low.

\section{Methodology:-}

\section{Research Time and Location}

Research on the study of the implementation of accrual - based accounting in local government entities was planned for 6-7 months in 2017. The study was conducted on 51 Regional Government Work Units (SKPD) of the Makassar City Regional Government of South Sulawesi.

\section{Research design}

This research includes survey research using instruments monitoring the implementation of accrual-based accounting. Based on the data analysis, this research was a quantitative research, because it analyzes sample data with inductive statistics and generalized descriptive statistics for the population conclusion (Indriartono and Supomo, 2002: 15). The data collected was cross sectional data, obtained from respondents in responding to indicators related to the assessment of elements of local government financial statements.

\section{The variables observed}

Accrual accounting-based implementation variables are measured using an index in the form of an instrument for monitoring the application of accrual-based accounting that was developed according to the characteristics set by Government Regulation No. 71 of 2010 concerning Government Accounting Standards. This index consists of elements of financial statements that each element was measured dichotomically. In full the index used can be seen in the following table. 
Table 1:-Accrual-Based Accounting Application Instrument for Local Government (based on PP No. 71 of 2010 concerning SAP)

\begin{tabular}{|l|l|}
\hline No. & Description \\
\hline 1. & Assessment of Financial Statements \\
\hline 2. & Assessment of Financial Statements (including SKPKD as SKPD) \\
\hline 3. & Assessment of Accounting Policies \\
\hline 4. & SAPD Assessment \\
\hline 5. & Assessment of Cash and Cash Equivalents \\
\hline 6. & Receivable Assessment \\
\hline 7. & Non-Permanent Investment Assessment \\
\hline 8. & Inventory Assessment \\
\hline 9. & Fixed Assets Assessment \\
\hline 10. & Construction Assessment in Progress \\
\hline 11. & Reserve Fund Assessment \\
\hline 12. & Other Asset Assessments \\
\hline 13. & Liabilities Assessment \\
\hline 14. & Equity Assessment \\
\hline 15. & LRA revenue Assessment \\
\hline 16. & Shopping Assessment \\
\hline 17. & Transfer Assessment \\
\hline 18. & LO Revenue Assessment \\
\hline 19. & Expense Assessment \\
\hline 20. & Financing Assessment \\
\hline
\end{tabular}

\section{Data and Instruments Used}

This study was conducted at the Regional Work Unit (SKPD) of the Makassar City Government of South Sulawesi Province. In 2017, the Makassar City Government has 51 SKPD. The data used in this study are primary data and secondary data. The primary data in question was data obtained from respondents through an instrument of monitoring the application of accrual-based accounting.

\section{Data analysis method}

The study of the implementation of accrual-based accounting in these local government entities was carried out with the index methodology in the form of instruments. The instruments are prepared according to the elements of the Financial Statements in the current Government Accounting Standards. The approach with index methodology has proven to be a useful method, because it allows general research from many aspects of reform, and has been used in a number of previous studies (Christiaens, 1999; Cohen and Kaimenakis, 2007).

Respondents were asked to answer "yes" (value $=1$ ) if they have applied an accounting system in accordance with Government Accounting Standards and "no" (value = 0) if not. Recapitulation The overall application index was calculated for each work unit as the sum of scores in all dichotomous variables; the work unit index will take the total value if it has applied according to accounting standards.

\section{Results:- \\ Respondent Data}

This research was conducted at the Makassar City Government in 2017. Since January 1, 2017 the Regional Work Unit (SKPD) in the Makassar City Government was 51 SKPD consisting of 25 Departments, 7 Agencies, 2 Secretariat, 1 Unit, 15 Districts, and 1 Inspectorate. The research instrument was distributed to all SKPD in the Makassar City Government. Each SKPD was given 3 instrument questionnaires, so there were 153 instrument questionnaires distributed. Until this data was processed, there were 26 questionnaires that had not been returned, so that only 127 instrument questionnaires were processed.

\section{Variable Measurement}

Variables are measured by using question items measured by two answer scores, namely a score of 1 (one) for the answer "Yes" and a score of 0 (zero) for the answer "No". The results of the calculation of index values based on the 
three box method can be concluded that the average index of the conclusions of the three box method of each variabel can be seen in the following table.

Table 2:-All Variable Index Figures

\begin{tabular}{|l|l|c|c|}
\hline \multicolumn{1}{|c|}{ Variable Name } & Variable Code & Index \\
No. & \multicolumn{1}{|c|}{$(\mathrm{X} 1)$} & 74.66 \\
\hline 1. & Cash and cash equivalents & $(\mathrm{X} 2)$ & 94.75 \\
\hline 2. & Receivable & $(\mathrm{X} 3)$ & 99.66 \\
\hline 3. & Non-Permanent & $(\mathrm{X} 4)$ & 100 \\
\hline 4. & Inventory & $(\mathrm{X} 5)$ & 98.52 \\
\hline 5. & Fixed assets & $(\mathrm{X} 6)$ & 99.61 \\
\hline 6. & Construction in progress & $(\mathrm{X} 7)$ & 100 \\
\hline 7. & Reserved fund & $(\mathrm{X} 9)$ & 100 \\
\hline 8. & Other Assets & $(\mathrm{X} 10)$ & 100 \\
\hline 9. & Liabilities & $(\mathrm{X} 11)$ & 100 \\
\hline 10. & Equity & $(\mathrm{X} 12)$ & 100 \\
\hline 11. & LRA revenue & $(\mathrm{X} 13)$ & 100 \\
\hline 12. & Shopping & $(\mathrm{X} 14)$ & 100 \\
\hline 13. & Transfer & $(\mathrm{X} 15)$ & 100 \\
\hline 14. & Financing & $(\mathrm{X} 16)$ & 100 \\
\hline 15. & LO revenue & & \\
\hline 16. & Expense & & \\
\hline
\end{tabular}

Source: processed primary data, 2017

From Table 2. can be seen the perception of respondents based on the instrument monitoring the application of the accrual-based states that 11 groups of accounts (variables) are in accordance with Government Accounting Standards. There are 5 accounts, namely cash and cash equivalents, accounts receivable, nonpermanent, fixed assets, construction in progress, and reserve funds that are not fully compliant with Government Accounting Standards.

Cash and equivalent accounts (variable) show the results of calculating index values for the variable Cash and Cash Equivalents (X1) was 74.66, this means that the perceptions of respondents believe there are still 25.34 not in accordance with Government Accounting Standards. This result was also supported by the results of the BPK's examination of the Makassar City's internal control system that there is still an orderly Treasurer of spending and dealing with money for regional expenditures (BPK .TA. 2014).

Furthermore, the accounts receivable shows the results of calculating the index value and it was known that the index value for the variable Receivable (X2) was 94.75. Based on the three box method concept, it can be concluded that the Receivable (X2) variable was included in the high category. However, there are still 5.25 that do not match SAP. This was in line with the results of the BPK's examination of the Makassar City internal control system that there are still records of tax receivables that are not orderly and do not reflect the entire claim rights of the Makassar City government. (BPK .TA.2014).

In the assessment of Non-permanent Investment shows the results of calculating the index value and it was known that the index value was 99.66. Based on the concept of the three box method it can be concluded that the variable non-permanent investment (X3) was included in the high category.

While the asset valuation still shows the results of calculating the index value and it was known that the index value for the fixed asset variable (X5) was 98.52. Based on the concept of the three box method, it can be concluded that the variable fixed assets (X5) are included in the high category. The results of BPK's examination of Makassar's internal control system that there was still inadequate recording and reporting of fixed assets. 


\section{Discuss}

The results of the study and analysis on the implementation of accrual-based accounting in government entities obtained an instrument form to monitor the implementation of a government policy in the accountability of regional financial management. The results of the study and analysis of the determinants of the implementation of accrual based accounting in government entities for the first year were obtained in the form of instruments to monitor the implementation of a government policy in regional financial management accountability. In addition, the results of this study as the development of accounting theory, especially the existing accounting theory of government. The results of this research study are used as a source of teaching material for government accounting subjects.

For the second year, the results of this study are expected to be continued by making a more complex study model. For the third year, in addition to developing a study model as well as developing research objects. For regional entities, the results of the study are expected to be used as material in developing resources within the local government organizational structure.

This research was in line with the second mission of Hasanuddin University, namely to preserve, develop, find, and create science, technology, art and culture. The mission implies that in conducting research and development activities to promote science and technology, it was always disseminated through learning activities (dharma 1), and was used to improve the welfare of the community through the field of community service (dharma 2).

\section{Next Stage Plan}

This research was designed for 3 years. In the first year, the study was carried out in the form of the preparation of instruments for monitoring the application of accrual-based accounting based on Government Accounting Standards according to Government Regulation (PP) No. 71 of 2010. The object of the study was the Financial Administration Officer (PPK) and the Regional Finance Management Officer (PPKD) of the Makassar City Government. First year research was designed using quantitative methods with descriptive analysis with index methodology.

The second year study was designed by developing a development model to examine more deeply the implementation of accrual - based accounting in local government entities. Development was carried out by examining the factors that influence the implementation of accrual - based accounting. Research in the third year, the development was carried out by adding objects of research and development models.

\section{Conclusions and Recommendations:-}

According to public policy implementation theory from George C. Edward (1980) that many factors influence the success of a policy implementation. These factors include: communication, resources, disposition, and bureaucratic structure. The successful implementation of a policy or regulation must also be supported by resources. Resources can be human resources or financial resources. In addition, the success of implementation was also supported by the disposition or character and characteristics of commitment, honesty, and democratic nature.

Testing of the implementation of accrual-based accounting policies that have been running for approximately two years is carried out in the form of instruments derived from the accrual-based accounting policy. Therefore, the instrument starts from general policies to elements of financial statements.

Based on the concept of the three box method, it can be concluded that of the 13 variables in the monitoring instrument monitoring the implementation of the accrual-based, respondents' perceptions stated that 11 groups of accounts (variables) were in accordance with Government Accounting Standards. There are 5 accounts, namely cash and cash equivalents, accounts receivable, non-permanent, fixed assets, construction in progress, and reserve funds that are not fully compliant with Government Accounting Standards.

And there are still many factors that influence the success of a policy implementation. These factors include: communication, resources, disposition, and bureaucratic structure. Therefore, testing the application of accrual based accounting policies was to examine the factors that influence the application of accrual - based accounting.

This study uses the concept of three box method, for the next research can be used other research methods. This research was used in the local government of Makassar City, further research can be carried out on other regional governments. 


\section{References:-}

1. Ahyaruddin, Muhammad. 2013. Tantangan Penerapan Akuntansi Berbasis Akrual di Pemerintahan Indonesia. (Online), (http://kaseiur.blogspot.co.id/2013/06/tantangan-penerapan-akuntansi-berbasis.html, accessed 4 January 2016).

2. Amriani, Tenry Nur. 2014. Menyongsong Penerapan Akuntansi Pemerintahan Berbasis Akrual. (Online), (http://www.bppk.kemenkeu.go.id/berita-makassar/19410-menyongsong-penerapan-akuntansi-pemerintahan berbasis-akrual, accessed s 5 February 2016).

3. BPK, 2014, Pemeriksaan Sistem Pengendalian Intern Pemerintah Kota Makassar

4. Bastian, Indra. 2010. Akuntansi Sektor Publik: Suatu Pengantar. Edisi ketiga. Jakarta: Erlangga.

5. Christiaens, J., 1999, 'Financial Accounting Reform in Flemish Municipalities: An Empirical Investigation', Financial Accountability \& Management, 15, 1, pp. 21640.

6. Christiaens, J., 2001, 'Converging New Public Management Reforms and Diverging Accounting Practices in Flemish Local Governments', Financial Accountability \&Management, 17, 2,pp. 153670.

7. Christiaens, J. and E. de Wielemaker, 2003, 'Financial Accounting Reform in Flemish Universities: An Empirical Study of the Implementation', Financial Accountability \& Management, 19, 2, pp. 1856204.

8. Christiaens, J. and Vanhee, C., 2001, Innovations in governmental accounting systems: the concept of a 'mega general ledger' in Belgian provinces, Research working paper Ugent, nr. 01/113, 27.

9. Christiaens, J. and Vanpeteghem, V., 2003, 'Governmental Accounting Reform: Evolution of the Implementation in Flemish Municipalities', Financial Accountability \& Management, 23, 4, pp. 3756399.

10. Cohen, S., Kaimenaki E. and Zorgios, Y., 2007, 'Assessing IT as a Key Success Factor for Accrual Accounting Implementation in Greek Municipalities',Financial Accountability and Management, 23, 1, pp. 916111.

11. Cohen, S., Kaimenaki E. and Zorgios, Y., 2007, 'How Different are Accrual Accounting Financial Measures Compared to Cash Accounting ones? Evidence from Greek Municipalities', 6th Annual Conference of the Hellenic Accounting and Finance Association, Patra, December 14615.

12. Edward III, George C (1980)," Implementing Public Policy”, Congressional Quarterly Press, Washington.

13. Guthrie, J., 1998, 'Application of Accrual Accounting in the Australian Public Sector - Rhetoric or Reality?',Financial Accountability \& Management, 14, 1, pp. 1-19.

14. Ismail, Juniati. 2016, Faktor-faktor yang Memengaruhi Implementasi SAP Berbasis Akrual Di Pemerintahan Gorontalo, Thesis S2 Program Magister Akuntansi FEB Unhas, Makassar, unpublished.

15. Jensen, M. C. \& Meckling, W. H. 1976. Theory of the Firm: Managerial Behavior, Agency Cost and Ownership Structure. Journal of Financial Economics, 3(4), 305-360.

16. Krumwiede K., 1998, 'The implementation stages of activity based costing and the impact of contextual and organizational factors', Journal of Management Accounting Research, 10, pp. 2396277.

17. Peraturan Pemerintah Republik Indonesia. 2003. Undang-Undang Nomor 17 Tahun 2003 tentang Keuangan Negara.

18. Peraturan Pemerintah Republik Indonesia. 2010. Nomor 71 Tahun 2010 tentang Standar Akuntansi Pemerintahan.

19. Robbins, W.A. and Austin, K.R., 1986, 'Disclosure quality in governmental financial report: An assessment of the appropriateness of a compound measure', Journal of Accounting Research, 24, 2, pp. 4126421.

20. Stamatiadis, F., Eriotis, N. And Vasiliou, D., 2009, "Assessing Accrual Accounting Reform in Greek Public Hospitals: An Empirical Investigation”.International Journal of Economic Science and Applied Research, 4, 1, pp 1536184.

21. Universitas Hasanuddin, 2016, "Rencana Strategis Universitas Hasanuddin 2016 - 2020, Makassar.

22. Usman, Sunandar, Ida Farida, 2014, “Analisis Faktor-faktor yang Mempengaruhi Implementasi Akuntansi Akrual pada Entitas Pemerintah Daerah”. Jurnal Akuntansi dan Investasi. Vol. 15 No. 2 Juli 2014. 